DR ABDALLA M ABDALLA (Orcid ID : 0000-0002-9782-529X)

Article type : Article

Synthesis and Electrochemical Characterization of $\mathrm{La}_{0.75} \mathrm{Sr}_{0.25} \mathrm{Mn}_{0.5} \mathrm{Cr}_{0.5}$ ${ }_{x} \mathrm{Al}_{\mathrm{x}} \mathrm{O}_{3}$, for IT and HT-SOFCs

\title{
Abdalla M. Abdalla ${ }^{a,}$, ,Madeha Kamel ${ }^{\text {a }}$, Shahzad Hossain, ${ }^{\text {b John T S Irvine }}{ }^{c}$, Abul K. Azad $^{\mathbf{d}^{*}}$
}

${ }^{a}$ Mechanical Engineering Department, Faculty of Engineering, Suez Canal University, Ismailia 41522, Egypt.

${ }^{b}$ Institute of Nuclear Science and Technology, Bangladesh Atomic Energy Commission, GPO Box No 3787, Dhaka 1000, Bangladesh.

${ }^{c}$ Center for Advanced Material, School of Chemistry, University of St Andrews, Fife KY169ST, Scotland, UK

${ }^{d}$ Faculty of Integrated Technologies, Universiti Brunei Darussalam, Gadong BE 1410, Brunei Darussalam.

*Corresponding author e-mail:abdalla.m.a1984@gmail.com, abul.azad@ubd.edu.bn Tel.: +201032029577

\begin{abstract}
The main emphasis of this work is to create a new perovskite material with three different compositions $\left(\mathrm{La}_{0.75} \mathrm{Sr}_{0.25} \mathrm{Mn}_{0.5} \mathrm{Cr}_{0.5-\mathrm{x}} \mathrm{AlxO}_{3}, \mathrm{x}=0.1,0.2,0.3\right)$ applied in both Intermediate and high Temperature - Solid Oxide Fuel Cells ( IT \& HT-SOFCs). Perovskite-type polycrystalline $\mathrm{La}_{0.75} \mathrm{Sr}_{0.25} \mathrm{Mn}_{0.5} \mathrm{Cr}_{0.5-\mathrm{x}} \mathrm{Al}_{\mathrm{x}} \mathrm{O}_{3-\delta}(\mathrm{x}=0.1,0.2,0.3)$ powders were synthesized and formed in a single phase structure by a dry chemistry route (standard solid-state reaction method). The effect of Al-doping on physicochemical and surface properties has been discovered.. The compounds were crystallized in single phase rhombohedral symmetry $(R-3 C$ Space. Group). Total conductivity of Al-doping in wet $5 \% \mathrm{H}_{2}$ was higher than both dry $5 \%$ $\mathrm{H}_{2}$ and air. The obtained results enhance the electro-catalytic performance and the material conductivity as well, which will be good for anode materials in IT- HT-SOFCs and the optimum doping is $10 \%$.
\end{abstract}

This article has been accepted for publication and undergone full peer review but has not been through the copyediting, typesetting, pagination and proofreading process, which may lead to differences between this version and the Version of Record. Please cite this article as doi: $10.1111 /$ ijac. 13375

This article is protected by copyright. All rights reserved. 
Keywords: XPS; Perovskite; Electrical conductivity; Binding Energy; AC conductivity.

\section{Introduction}

The essential demand for clean/green energy with long-term stability, conversion efficiency and effective economic investment, solid oxide fuel cell (SOFC) is one of the best promising technology to be considered[1]. Thus, researches and investigations of SOFCs are very encouraging especially for new energy conversion devices[2,3].

Mainly, a fuel cell consist of two porous electrodes (an anode and cathode) detached by a highly dense electrolyte material. High electric conductivity, redox stability and chemical adapting with the electrolyte are the primary key requirements for anode materials. Presently, redox stability under $\mathrm{H}_{2}$ fuel is one of the major concerns in developing new electrode materials. Hence, the state-of-the-art anode material, Ni/YSZ cermets, give poor redox cycling under hydrocarbon fuels and low tolerance to sulfur. $\mathrm{La}_{0.75} \mathrm{Sr}_{0.25} \mathrm{Cr}_{0.5} \mathrm{Mn}_{0.5} \mathrm{O}_{3-\delta}$ (LSCM), a perovskite oxide, has been proved to be potential anode material that can overcome these problems[4,5].

In structural level, the properties of mixed metal oxides are complex. This is more apparent when the oxide contains more than one magnetic species, or when the crystal structure permits some degree of atomic disorder [6,7]. $\mathrm{La}_{0.75} \mathrm{Sr}_{0.25} \mathrm{Mn}_{0.5} \mathrm{Cr}_{0.5} \mathrm{O}_{3-\delta}$ can be considered as a solid solution of $\mathrm{La}_{1-\mathrm{x}} \mathrm{Sr}_{\mathrm{x}} \mathrm{CrO}_{3}$ and $\mathrm{La}_{1-\mathrm{x}} \mathrm{Sr}_{\mathrm{x}} \mathrm{MnO}_{3}$. Substitution of $\mathrm{Sr}$ at the A-site and $\mathrm{Cr}$ at the $\mathrm{B}$-site in $\mathrm{LaMnO}_{3}$ gives rise to various interesting magnetic[8] and electrical properties [9]. $\mathrm{LaMnO}_{3}$-based materials were identified as good anodes in SOFCs fed with hydrocarbon fuels [10]. Often, $\mathrm{La}_{1-\mathrm{x}} \mathrm{Sr}_{\mathrm{x}} \mathrm{MnO}_{3-\delta}$ is used as cathode materials for its high conductivity and stability in oxidation conditions[11-14]. $\mathrm{La}_{1-\mathrm{x}} \mathrm{Sr}_{\mathrm{x}} \mathrm{CrO}_{3-\delta}$ can be used as interconnects materials for its high stability in anodic conditions. It was found that the introduction of transition metals into the $\mathrm{B}$-site of $\mathrm{La}_{1-\mathrm{x}} \mathrm{Sr}_{\mathrm{x}} \mathrm{Mn}_{1-\mathrm{y}} \mathrm{M}_{\mathrm{y}} \mathrm{O}_{3}(\mathrm{M}=\mathrm{Cr}, \mathrm{Fe}, \mathrm{Co}, \mathrm{Ni})$ can improve the catalytic properties for hydrocarbon reforming $[15,16]$. The double doped perovskite phases are stable within redox conditions, showing a little volume change chemically and physically compatible with interconnect materials.

Yaremchenko et al.[17] reported the substitution of Fe with $\mathrm{Cr}$ and $\mathrm{Al}$ in $\mathrm{La}_{0.3} \mathrm{Sr}_{0.7} \mathrm{Fe}_{1-\mathrm{x}-}$ ${ }_{y} \mathrm{Al}_{\mathrm{x}} \mathrm{Cr}_{\mathrm{y}} \mathrm{O}_{3-\delta}$ decreased the total conductivity, $\mathrm{O}_{2}$ permeability and thermal expansion coefficient. However, $\mathrm{La}_{0.3} \mathrm{Sr}_{0.7} \mathrm{Fe}_{0.5} \mathrm{Cr}_{0.5} \mathrm{O}_{3-\delta}$ was stable under a reducing atmosphere, but its 
electrochemical performance in wet $\mathrm{CH}_{4}$ was noted to be poor [9]. So, considering the catalytic activity and cracking resistance $(\mathrm{LaSr})(\mathrm{CrNi}) \mathrm{O}_{3}$ with $10 \% \mathrm{Ni}$ doping suggested being more suitable for a $\mathrm{CH}_{4}$ oxidation reaction [10]. In contrast, to Ni/YSZ cermets, a $\mathrm{La}_{0.75} \mathrm{Sr}_{0.25} \mathrm{Mn}_{0.5} \mathrm{Cr}_{0.5} \mathrm{O}_{3}$ electrode is active for the electro-oxidation of $\mathrm{CH}_{4}$ at higher temperatures in the absence of excess steam. However, the relative contributions of direct oxidation and internal reforming have yet to be determined.

J.M. Porras-Vázquez et al [18] have reported the Al-doped $\mathrm{Sr}_{2} \mathrm{SiO}_{4}$ as electroyte materials in SOFCs devices and showing that $\mathrm{Al}$ doping content increases the amount of holes resulting in higher p-type electronic conductivity. In addition to highest value of $3.0 \times 10^{-5} \mathrm{~S} \mathrm{~cm}^{-1}$ in wet $\mathrm{N} 2$ at IT of $800{ }^{\circ} \mathrm{C}$. While Nicoleta Cioatera et al [19] have shown a great enhancement of the $\mathrm{Al}$ doped material $\left\{\mathrm{Sm}_{2} \mathrm{Ti}_{2-\mathrm{x}} \mathrm{Al}_{\mathrm{x}} \mathrm{O}_{7-\mathrm{d}}(\mathrm{x}=0,0.1,0.2)\right\}$ in the electrical conductivity with lower activation energy of $0.64 \mathrm{eV}$ at temperature lower than $700{ }^{\circ} \mathrm{C}$.

The addition of $\mathrm{Cr}$ have been reported by Agnieszka $\mathrm{La}$ c cz et al [20] in formula $\mathrm{SrTi}_{1-\mathrm{x}} \mathrm{Cr}_{\mathrm{x}} \mathrm{O}_{3}$ (where $\mathrm{x}=0,1,4,6 \mathrm{~mol} \%$ ) by wet chemistry route, showing a good enhancement in the conductivity properties with a minimum value of activation energy $0.44 \pm 0.01 \mathrm{eV}$. But Yinghua Niu et al [21] have shown in their investigation, that applying $\mathrm{Cr}$ in SOFCs electrodes is impacted by many factors and the electrochemical performance is mainly related to the microstructure and doping percentages of $\mathrm{Cr}$.

XPS enables the study of changes in chemistry as well as in electrostatic potentials of atoms in materials. Ions of an oxide may exhibit modified chemical surface states e.g. different oxidations numbers or neighbouring atoms because the chemical environment of surface ions is different from the bulk. Electrochemical polarization and atmosphere effects on the BEs along with surface species requires to be investigated for a mechanistic interpretation of oxygen exchange kinetics. Less information about surface chemistry of perovskite-type anodes and cathodes other than $\mathrm{La}_{0.6} \mathrm{Sr}_{0.4} \mathrm{CoO}_{3-\mathrm{d}}$ [22-23].

In the current research, three new compositions $\mathrm{La}_{0.75} \mathrm{Sr}_{0.25} \mathrm{Mn}_{0.5} \mathrm{Cr}_{0.5-\mathrm{x}} \mathrm{Al}_{\mathrm{x}} \mathrm{O}_{3-\delta}(\mathrm{x}=0.1,0.2$, 0.3) were synthesised to discover the effect of Al-doping on physicochemical and surface properties. Substitution of $\mathrm{Al}$, a trivalent cation, with $\mathrm{Cr}$ resulted in an interesting changes in electrical properties, magnetic properties and the cation valence state [24]. Structural, electrical and surface characterisations of these materials are useful for fundamental understanding and applications of electrode materials in SOFCs devices. These 
characterisations will help to identify the practical applications of these compounds, particularly applications in both IT \& HT-SOFCs.

\section{Experimental}

Single perovskite-type polycrystalline $\mathrm{La}_{0.75} \mathrm{Sr}_{0.25} \mathrm{Mn}_{0.5} \mathrm{Cr}_{0.5-\mathrm{x}} \mathrm{Al}_{\mathrm{x}} \mathrm{O}_{3-\delta}(\mathrm{x}=0.1,0.2,0.3)$ (later mentioned as LSCMA1, LSCMA2 and LSCMA3) powders were formed in a single phase by standard solid-state reaction method. Stoichiometric amounts of high-purity $\mathrm{La}_{2} \mathrm{O}_{3}, \mathrm{SrCO}_{3}$, $\mathrm{MnO}, \mathrm{Cr}_{2} \mathrm{O}_{3}$ and $\mathrm{Al}_{2} \mathrm{O}_{3}$ powders were ground under acetone. The samples were mixed together and first dried at 350 for preliminary heating and humidity releasing. After weighting the chemicals and it has been mixed again with aceton in agate mortar pestle before sonication process for 1 hour. Later on powders were collected and well dried in fume hood. The treatment of the compounds started by first calcination at $1100{ }^{\circ} \mathrm{C}$ for 6 hours. The next step was firing the samples at $1300 \mathrm{C}$ for 12 hours then followed by an X-Ray Diffraction (XRD) checking. The synthesized materials were not pure yet so the final sintering step was achieved at $1500^{\circ} \mathrm{C}$ for 24 hours in $5{ }^{\circ} \mathrm{C} / \mathrm{min}$ as a heating and cooling rate in air and pure single phase structures were obtained.

XRD data were obtained using a transmission type Stoe Stadi-P diffractometer $\left(\mathrm{CuK \alpha} \alpha_{1}=1.540598 \AA\right)$ to determine phase purity and measure crystal structure parameters. XRD data were collected in the $2 \theta$ range from 10 to $90^{\circ}$ with a $0.01^{\circ}$ step size and count time of $70 \mathrm{~s}$ step.XRD patterns were indexed using the automatic indexing program TREOR90[21-25]. SPuDS [22-26] software was used to find the preliminary atomic positions and unit cell parameters. Rietveld analysis of the obtained XRD data was done through FullProf program [23-27]. A pseudo-Voigt function quantified the shapes of diffracted peak, applying angles a symmetry peak correction below $45^{\circ}$ in $2 \theta$.

Measurements of AC impedance were performed on $13 \mathrm{~mm}$ diameter pellets with $\mathrm{Pt}$ electrode painted on both sides using a Schlumberger Solartron 1260 electrochemical impedance analyzer in the frequency range of $1 \mathrm{~Hz}$ to $1 \mathrm{MHz}$ in $50{ }^{\circ} \mathrm{C}$ steps in air, dry $5 \% \mathrm{H}_{2} / \mathrm{Ar}$ and wet $5 \% \mathrm{H}_{2} / \mathrm{Ar}$ in the range 300 to $900{ }^{\circ} \mathrm{C}$.

XPS spectra were collected on powders using an ESCALAB II spectrometer (V.G., UK) using an $\mathrm{Al} \mathrm{K \alpha}(\mathrm{h} v=1486.6 \mathrm{eV}) \mathrm{X}$-ray source with $5 \mathrm{sec}$ acquisition time. A hemispherical electron analyser having constant energy mode was used to measure the photoelectrons kinetic energies. In addition to, the characterisation of the surface and several near surface 
layers were achieved at a take-off angle of $45^{\circ}$. BEs were calibrated relative to the $\mathrm{C} 1 \mathrm{~s}$ peak from carbon contamination of the tested samples at $284.9 \mathrm{eV}$ to correct for charging effects. High resolution spectral envelops were obtained by curve fitting in XPS peak software. The data were used with no preliminary smoothing. Symmetric Gaussian-Lorentzian peak functions were used to convergent the line shapes of the fitting components. The estimation of Peak intensities were achieved by the integral calculating of each peak after a Shirley background subtraction.

\section{Results and Discussion}

A. Structural analysis

Rietveld structure refinements of the obtained XRD data confirm the single-phase with cationic stoichiometry close to the ideal value. Fig. 1 shows the Rietveld fitted XRD profile of $\mathrm{La}_{0.75} \mathrm{Sr}_{0.25} \mathrm{Mn}_{0.5} \mathrm{Cr}_{0.3} \mathrm{Al}_{0.2} \mathrm{O}_{3-\delta}$. Small amount of oxygen deficiency was observed which might be due to the divalent $\mathrm{Sr}$ substitution with tri-valent La. Oxygen vacancy can also be related to the valence state of $\mathrm{Mn}$ and $\mathrm{Cr}$. Since oxygen vacancy has a strong effect on both ionic and electronic conductivities, it is important to study the valence state of the constituting atoms in the composition. All three compositions have showed distorted structure; crystallized in the rhombohedral symmetry in R-3Cs.g (no. 167). The refined cell parameters, atomic positions and R-factors from XRD data refinement are listed in Table 1.

\section{B. Electrical Conductivity}

Electrochemical impedance measurements in air, dry $5 \% \mathrm{H}_{2}$ and wet $5 \% \mathrm{H}_{2}$ shows that the conductivities decreases with the increase of Al-doping in all three environments. In wet $5 \% \mathrm{H}_{2}$, the total conductivity for $\mathrm{x}=0.1$ samples was $0.46 \mathrm{~S} / \mathrm{cm}$ at $870{ }^{\circ} \mathrm{C}$, which was reduced to 0.32 and $0.30 \mathrm{~S} / \mathrm{cm}$ for $\mathrm{x}=0.2$ and 0.3 , respectively. The corresponding activation energies were calculated to be $0.087,0.069$ and $0.084 \mathrm{eV}$. For dry $5 \% \mathrm{H}_{2}$, the total conductivities were $0.39,0.14$ and $0.24 \mathrm{~S} / \mathrm{cm}$ with activation energies of $0.26,0.22$ and $0.31 \mathrm{eV}$. In air, the total conductivities were $0.25,0.16,0.17 \mathrm{~S} / \mathrm{cm}$ and the activation energies were $0.34,0.33$ and $0.41 \mathrm{eV}$. The doping of both $\mathrm{Cr}$ and $\mathrm{Al}$ have shown a good enhancement and stability of electrical conductivities especially for $\mathrm{x}=0.1$ with lower activation energy value of 0.087 $\mathrm{eV}$. Meanwhile, the doping of $\mathrm{Cr}$ is lowering [20] the oxidation state but doping of $\mathrm{Al}$ increases the oxygen vacancy concentration [19] which gives more stability in electrochemical transportation of ions. Fig. 2 shows the Arrhenius plots for all samples and 
table 2 lists the summarized conductivity results and how its varying with doping percentage of $\mathrm{Cr}$ and $\mathrm{Al}$.

\section{Isothermal conductivity measurements}

Fig. 3 is showing the change in isothermal conductivity according to Brouwer diagram, which the LSCMA perovskite was investigated and measured. The logarithmic plots of the equilibrium total conductivity versus the logarithm of $\mathrm{pO} 2$ for $\mathrm{x}=0.1$ and $\mathrm{x}=0.2$ at $900{ }^{\circ} \mathrm{C}$, The $\mathrm{pO} 2$ test temperature was selected to be within the structural stability limit of the LSCM doped materials. The Slope of linear fitting in the high pO2 corresponds to slope of $1 / 12 \mathrm{~m}$ where isothermal conductivity changes in the concentration of the various charge collated to pO2. The obtained data have shown a steady state/stable equilibration with a higher value of the measured conductivity for $\mathrm{x}=0.1$, basically, this is happened due to the reduction of $\mathrm{Mn}$

$4+$ to Mn 3+ and atomic oxygens from the unit cell as made by Irvine et al [24]. However, the tested specimens showed a small change in the isothermal conductivity along the same variation with $\mathrm{pO} 2$ for $\mathrm{x}=0.1$ and $\mathrm{x}=0.2$ at higher temperature, But it leads to an equal concentrations of electron- and hole-like carriers in the material.

\section{XPS analysis:}

The chemical state of the elements and the surface properties of $\mathrm{La}_{0.75} \mathrm{Sr}_{0.25} \mathrm{Mn}_{0.5} \mathrm{Cr}_{0.5-\mathrm{x}} \mathrm{Al}_{\mathrm{x}} \mathrm{O}_{3-\delta}$ $(\mathrm{x}=0.1,0.2,0.3)$ were determined by XPS. BEs were determined from the fittings of the main peaks of $\mathrm{C} 1 \mathrm{~s}, \mathrm{Sr} 2 \mathrm{p}, \mathrm{Cr} 2 \mathrm{p}, \mathrm{Mn} 2 \mathrm{p}, \mathrm{Al} 2 \mathrm{p}$ and $\mathrm{O} 1 \mathrm{~s}$ levels for as-prepared and prereduced samples. To illustrate the wide spectral features of the samples, the $\mathrm{C} 1 \mathrm{~s}, \mathrm{Sr} 3 \mathrm{~d}, \mathrm{Mn}$ $2 \mathrm{p}$ and $\mathrm{Cr} 2 \mathrm{p}$ core level spectra are shown in Fig.4.

Fig.4 illustrates that $\mathrm{La}, \mathrm{Sr}, \mathrm{Mn}, \mathrm{Cr}, \mathrm{Al}, \mathrm{C}$ and $\mathrm{O}$ elements were detected on the surface of the powders. The calibration process of the BE resulted in carbon $(\mathrm{C}-\mathrm{H})$ on the surface which occurred due to the atmospheric contamination and was used as the standard reference for the XPS results. It gave a strong peak near $284.6 \mathrm{eV}$. The evidence of segregated carbonate presence with inorganic substances located near the $288.86 \mathrm{eV}$ is responsible for the surface state of the reforming catalyst powders [28]. BEs of the selected elements is summarized in Table 3. BEs were determined from the fitting of the main peaks in the lanthanide $3 \mathrm{~d}$ core level spectra and decomposed peaks of $\mathrm{La}_{0.75} \mathrm{Sr}_{0.25} \mathrm{Mn}_{0.5} \mathrm{Cr}_{1-\mathrm{x}} \mathrm{Al}_{\mathrm{x}} \mathrm{O}_{3-\delta}$. The core level $3 \mathrm{~d}_{5 / 2}$ for $\mathrm{La}_{2} \mathrm{O}_{3}$ is conventionally observed near $834.4 \mathrm{eV} . \mathrm{La}_{0.75} \mathrm{Sr}_{0.25} \mathrm{Mn}_{0.5} \mathrm{Cr}_{1-\mathrm{x}} \mathrm{Al}_{\mathrm{x}} \mathrm{O}_{3-\delta} \quad(\mathrm{x}=0.1$, 
0.2,0.3) samples shown in Fig.4 are consistent with normal oxidations $\mathrm{La}^{3+}$. They were well substituted into the A site of the precursors and sustained a charge state of $3+$.

The Chemical state of La is generally well-known from XPS spectra[28,29]. La 3d states splits into two lines. Both of $3 \mathrm{~d}_{5 / 2}$ and $3 \mathrm{~d}_{3 / 2}$ spilt because of the released electron from $\mathrm{O}_{2}$ ligands of La 4f. This phenomenon results from defected crystals[30]. Also, La in perovskites shows low $\mathrm{BEs}$ than that of $\mathrm{La}$ in $\mathrm{La}_{2} \mathrm{O}_{3}$ because of a low interaction between Location and the transition metal element in perovskites [29].

Fig.5 shows the measured XPS spectra and the deconvolution results of $\mathrm{Mn}, \mathrm{Cr} 2 \mathrm{p}_{1 / 2}$ and $2 p_{3 / 2}$ in the LSCMA that was heat-treated under the oxidizing conditions (in air) and were found to include 3 peaks for $\mathrm{x}=0.1,2$ peaks for $\mathrm{x}=0.2$ and 2 peaks for $\mathrm{x}=0.3$ for $\mathrm{Mn}$. For $\mathrm{Cr}$, we observed 2 peaks for $\mathrm{x}=0.1,4$ peaks for $\mathrm{x}=0.2$ and 3 peaks for $\mathrm{x}=0.3$. The split of the Mn peaks 2d level spectrum is due to spin-orbit splitting. The Full Width at Half Maximum (FWHM) values of the Mn peaks were increased with Al doping and became maximum at $\mathrm{x}=0.3$. BEs of $641.90 \mathrm{eV}, 641.39 \mathrm{eV}$ and $644.22 \mathrm{eV}$ represent the $2 \mathrm{p}_{3 / 2} \mathrm{of} \mathrm{Mn}^{+2}$, $\mathrm{Mn}^{+3}$ and $\mathrm{Mn}^{+4}$, respectively, according to the literature[28],[31-34]. BEs at $653.60 \mathrm{eV}$, $651.92 \mathrm{eV}$ and $655.57 \mathrm{eV}$ represent the $2 \mathrm{p}_{1 / 2}$ of $\mathrm{Mn}^{+2}, \mathrm{Mn}^{+3}$ and $\mathrm{Mn}^{+4}$, respectively. For the Cr $2 d$ level spectrum, there were similar values of exchange splitting [35] due to many of the valence/spin-state regions in the studied samples [36]. In the XPS spectra the pure oxides $\mathrm{Cr}^{+3}$ and $\mathrm{Cr}^{+4}$ are quite difficult to distinguish [16]. BEs at $576.07 \mathrm{eV}, 575.51 \mathrm{eV}$ and 578.43 $\mathrm{eV}$ represents the $2 \mathrm{p}_{3 / 2}$ of $\mathrm{Cr}^{+3}, \mathrm{Cr}^{+4}$ and $\mathrm{Cr}^{+6}$, respectively. The BEs at $585.20 \mathrm{eV}$ and 587.86 $\mathrm{eV}$ represent the $2 \mathrm{p}_{1 / 2}$ of $\mathrm{Cr}^{+4}$ and $\mathrm{Cr}^{+6}$. The increase of satellite peaks in the $\mathrm{La}_{0.75} \mathrm{Sr}_{0.25} \mathrm{Mn}_{0.5} \mathrm{Cr}_{1-\mathrm{x}} \mathrm{Al}_{\mathrm{x}} \mathrm{O}_{3-\delta}$ with the dopant percentages with $\mathrm{Mn}$ and $\mathrm{Cr}$ indicates high electrochemical, electronic and electro-catalytic performance [31,36].

Fig.6 illustrates the XPS plots for $\mathrm{Mn}$ and $\mathrm{Cr}$ on reduced samples for $\mathrm{La}_{0.75} \mathrm{Sr}_{0.25} \mathrm{Mn}_{0.5} \mathrm{Cr}_{1-}$ ${ }_{\mathrm{x}} \mathrm{Al}_{\mathrm{x}} \mathrm{O}_{3-\delta}(\mathrm{x}=0.1,0.2,0.3)$. The BEs shown in Table 2 represent a distinct increase after prereduced condition for composition $\mathrm{x}=0.1$ and 0.2 and there is a small decrease for $\mathrm{x}=0.3$ in both cases for $\mathrm{Mn}$ and $\mathrm{Cr}$. This decrease is due to $\mathrm{La}_{2} \mathrm{O}_{3}$ which was highly dispersed on the surface[37]. In addition to the formation of $\mathrm{Mn}_{2} \mathrm{O}_{3}$ in as-prepared and pre-reduced samples, shown by $\mathrm{Mn} 2 \mathrm{p}_{3 / 2}$ considering the depth analysis by XPS, the photoemitted electrons increased with increasing kinetic energy [38]. Hence, the $M n 2 p_{1 / 2}$ is more sensitive than $2 p_{3 / 2}$ to the surface of $\mathrm{La}_{0.75} \mathrm{Sr}_{0.25} \mathrm{Mn}_{0.5} \mathrm{Cr}_{1-\mathrm{x}} \mathrm{Al}_{\mathrm{x}} \mathrm{O}_{3-\delta}$ specifically for $\mathrm{x}=0.3$. Subsequently, the 
oxidation conditions affect the valance state of $\mathrm{Mn}^{+2}, \mathrm{Mn}^{+3}$ and $\mathrm{Mn}^{+4}$.However, the findings in $\mathrm{Cr}^{+3}$ and $\mathrm{Cr}^{+6}$ agree with literature data [39] and the reference spectrum. The occurred deviation is due to the depth distribution in the analysed samples [38,39].

$\mathrm{Al}_{2} \mathrm{O}_{3}$ is a highly attractive material from thermal and chemical stability perspective [40].It able to increase the total BEs while doped with $\mathrm{La}^{3+}$ precursors [41]. The XPS spectra of $\mathrm{Al}$ 2p of $\mathrm{La}_{0.75} \mathrm{Sr}_{0.25} \mathrm{Mn}_{0.5} \mathrm{Cr}_{1-\mathrm{x}} \mathrm{Al}_{\mathrm{x}} \mathrm{O}_{3-\delta}$ are shown in Fig.7 and were plotted for as-prepared and pre-reduced samples.

Previous studies complemented that the occurrence of $\mathrm{La}^{+3}$ is near to the $\mathrm{Al}$ surface[42-44]. The La dopant may form $\mathrm{La}_{2} \mathrm{O}_{3}$ or $\mathrm{LaAlO}_{3}$ layer on the $\mathrm{Al}$ surface[ 44,45].The BEs of the $\mathrm{Al}$ $2 p$ line is listed inTable 2 after fitting of the mean peaks. BEs of $71.90 \mathrm{eV}$ and $76.93 \mathrm{eV}$ for $\mathrm{x}=0.1$ and the BEs of $72.94 \mathrm{eV}$ and $72.01 \mathrm{eV}$ for $\mathrm{x}=0.2$ and 0.3 ,of the as-prepared samples represent $\mathrm{Al}$ as a metallic state with closely spaced spin-orbit components. BEs of $75.93 \mathrm{eV}$ for $\mathrm{x}=0.2$ and $74.64 \mathrm{eV}$ for $\mathrm{x}=0.3$ in the pre-reduced samples acquire an oxide peak position. The spectra demonstrate BEs changes with and without reduction state which is due to exhibit energy loss features on the $\mathrm{Al}_{2} \mathrm{O}_{3}$ surface. According to the obtained results it is emphasized that the $\mathrm{La}^{3+}$ dopant remains dispersed as isolated atoms on the $\mathrm{Al}$ surface[46].

In the XPS spectra of $\mathrm{O} 1 \mathrm{~s}$, the BEs can be separated into two groups of perovskites containing $\mathrm{O}_{2}$ : Low $\mathrm{BE}$ and High $\mathrm{BE}$ [29]. The XPS spectra of $\mathrm{O} 1 \mathrm{~s}$ for the $\mathrm{La}_{0.75} \mathrm{Sr}_{0.25} \mathrm{Mn}_{0.5} \mathrm{Cr}_{1-\mathrm{x}} \mathrm{Al}_{\mathrm{x}} \mathrm{O}_{3-\delta}(\mathrm{x}=0.1,0.2,0.3)$ are shown in Fig.7. Two main peaks are clearly observed and their values were found to be higher than $530.02 \mathrm{eV}$. In Fig.8 and Table 2 about O1s peak, LBE of $530.62 \mathrm{eV}(\mathrm{x}=0.1), 532.52 \mathrm{eV}(\mathrm{x}=0.2)$ and $531.01 \mathrm{eV}(\mathrm{x}=0.3)$ correspond to the $\mathrm{O}_{2}$ in the lattice and HBE of $534.14 \mathrm{eV}(\mathrm{x}=0.1), 535.85 \mathrm{eV}(\mathrm{x}=0.2)$ and 533.7 $\mathrm{eV}(\mathrm{x}=0.3)$ indicate adsorbed oxygen-containing species near the surface. The value of percentage area of the $\mathrm{O}_{2}$ peaks reduced with the Al-doping i.e. 25.49, 14.63 and 11.93 for $\mathrm{x}$ $=0.1,0.2$ and 0.3 , respectively. When the value of percentage area of the $\mathrm{O}_{2}$ peaks with respect to the LBE shows lower value than other compositions, less $\mathrm{O}_{2}$ vacancies are generated on the surfaces of LSCMA. The maximum BE was observed to be532.52 eV at $\mathrm{x}=0.2$ which attributed to a broader peak and assigned to surface adsorbed $\mathrm{O}_{2}$ species[16, $28,47]$. The overall composition is mainly $\mathrm{O}^{2-}$ because of the lattice $\mathrm{O}_{2}$ on the surface. XPS spectra of $\mathrm{O} 1 \mathrm{~s}$ reveal a different propensity of BEs due to the $\mathrm{O}_{2}$ penetration path of each composition in the precursor being largely different in $\mathrm{La}_{0.75} \mathrm{Sr}_{0.25} \mathrm{Mn}_{0.5} \mathrm{Cr}_{1-\mathrm{x}} \mathrm{Al}_{\mathrm{x}} \mathrm{O}_{3-\delta}$.

This article is protected by copyright. All rights reserved. 


\section{Conclusions}

- Rietveld structure refinements of the obtained XRD data confirmed the single-phase with cationic stoichiometry close to the ideal value. Small amount of oxygen deficiency was observed. In addition to, all three compositions showed distorted structure; crystallized in the rhombohedral symmetry in R-3C s.g (no. 167).

- Electrochemical impedance analysis showed that the proposed perovskite materials $\mathrm{La}_{0.75} \mathrm{Sr}_{0.25} \mathrm{Mn}_{0.5} \mathrm{Cr}_{1-\mathrm{x}} \mathrm{Al}_{\mathrm{x}} \mathrm{O}_{3-\delta} \quad(\mathrm{x}=0.1,0.2, \quad 0.3)$ are highly conductive. The conductivities decreases with the increase of Al-doping in all three environments (wet $\mathrm{H}_{2}$, dry $\mathrm{H}_{2}$ and air). The total conductivities are higher in wet $\mathrm{H}_{2}$ than in dry $\mathrm{H}_{2}$ or air.

- A steady state/stable equilibration with a higher value of the measured conductivity for $x=0.1$ was obtained. However, the tested specimens showed a small change in the isothermal conductivity along the same variation with $\mathrm{pO} 2$ for $\mathrm{x}=0.1$ and $\mathrm{x}=0.2$ at higher temperature, But it leads to an equal concentrations of electron- and hole-like carriers in the material.

- Binding energies of nonredox active elements ( $\mathrm{La}, \mathrm{Sr}, \mathrm{O}, \mathrm{Al}$ ) showed a pronounced dependence on the atmosphere and the electrochemical polarization. Fermi level shift resulted from defect chemical models of oxygen has a strong influence on the binding energy shift.. Only the transition metals manganese and chromium appear to undergo valence changes. However, in oxidizing atmosphere near surface manganese is present as $\mathrm{Mn}^{3+}$, irrespective of polarization. In reducing atmosphere, manganese is present in the oxidation states as $\mathrm{Mn}^{3+}$ and $\mathrm{Mn}^{2+}$.

- Promising enhancement in the electro-catalytic performance and the material conductivity were achieved, which will be good for anode materials in IT- HT-SOFCs and the optimum doping is $10 \%$ (i.e. $\mathrm{La}_{0.75} \mathrm{Sr}_{0.25} \mathrm{Mn}_{0.5} \mathrm{Cr}_{1-\mathrm{x}} \mathrm{Al}_{\mathrm{x}} \mathrm{O}_{3-\delta}$ with $\mathrm{x}=0.1$ ).

\section{Acknowledgements}

The authors, A M Abdalla and S Hossain, are grateful to Suez Canal University and Universiti Brunei Darussalam and there collaborative for supporting this research work.

This article is protected by copyright. All rights reserved. 


\section{References}

1. Atkinson A, Barnett S, Gorte R J, Irvine J T S, McEvoy A J, Mogensen M, et al. Advanced anodes for high-temperature fuel cells. Nat. Mater. 2004;3: 17-27.

2. Steele B C, Heinzel A. Materials for fuel-cell technologies. Nature. 2001;414: 345352.

3. Hossain S, Abdalla A M, Jamain S N B, Zaini J H, Azad A K. A review on proton conducting electrolytes for clean energy and intermediate temperature-solid oxide fuel cells. Renew. Sustain. Energy Rev.2017; 79:750-764.

4. Tao S, Irvine J T S. A redox-stable efficient anode for solid-oxide fuel cells. Nat. Mater. 2003;2: 320-323.

5. Ghosh A, Azad A, Irvine J T S. Study of Ga Doped LSCM as an Anode for SOFC. ECS Trans. 2011;1337-1343.

6. Azad A K, Irvine J T S. Characterization of $\mathrm{YSr}_{2} \mathrm{Fe}_{3} \mathrm{O}_{8-\mathrm{d}}$ as electrode materials for SOFC, Solid State Ionics. 2001;192: 225-228.

7. Azad A K, Mellergård A, Eriksson S G, Ivanov S A, Yunus S M, Lindberg F, et al. Structural and magnetic properties of $\mathrm{LaFe}_{0.5} \mathrm{Cr}_{0.5} \mathrm{O}_{3}$ studied by neutron diffraction, electron diffraction and magnetometry. Mater. Res. Bull.2005;40:1633-1644.

8. Sun Y, Tong $\mathrm{W}, \mathrm{Xu} \mathrm{X}$, Zhang Y. Tuning colossal magnetoresistance response by $\mathrm{Cr}$ substitution in $\mathrm{La}_{0.67} \mathrm{Sr}_{0.33} \mathrm{MnO}_{3}$, Appl. Phys. Lett. 2001;78: 643-645.

9. Tao S, Irvine J. Investigation of the mixed conducting oxide ScYZT as a potential SOFC anode material, J. Electrochem. Soc. 2004;151:A497.

10. Primdahl S, Hansen J R, Grahl-Madsen L, Larsen P H. Sr-Doped $\mathrm{LaCrO}_{3}$ Anode for Solid Oxide Fuel Cells, J. Electrochem. Soc. 2001;148: A74.

11. Jiang S P, Zhang J P, Zheng X G. A comparative investigation of chromium deposition at air electrodes of solid oxide fuel cells, J. Eur. Ceram. Soc. 2002;22:361-373.

12. Vernoux P, Djurado E, Guillodo M. Catalytic and Electrochemical Properties of Doped Lanthanum Chromites as New Anode Materials for Solid Oxide Fuel Cells. J. Am. Ceram. Soc. 2001;95: 2289-2295.

13. Huang K, Wan J, Goodenough J B. Oxide-ion conducting ceramics for solid oxide fuel cells, J. Mater. Sci. 200;36:1093-1098.

14. Sauvet L, Fouletier J. Catalytic properties of new anode materials for solid oxide fuel cells operated under methane at intermediary temperature, J. Power Sources. 2001;101: 259-266.

15. Sfeir J, Buffat P A, Ockli P, Xanthopoulos N, Vasquez R, Mathieu H J, et al. 
Lanthanum Chromite Based Catalysts for Oxidation of Methane Directly on SOFC Anodes. J. Catal. 2001;202: 229-244.

16. Rida K, Benabbas A, Bouremmad F, Pea M.A, Martnez-Arias A. Surface properties and catalytic performance of $\mathrm{La}_{1-\mathrm{x}} \mathrm{Sr}_{\mathrm{x}} \mathrm{CrO}_{3}$ perovskite-type oxides for $\mathrm{CO}$ and $\mathrm{C}_{3} \mathrm{H}_{6}$ combustion, Catal. Commun. 2006;7:963-968.

17. Yaremchenko A A, Kharton V V, Shaula AL, Patrakeev M V, Marques F M B. Transport properties and thermal expansion of perovskite-like $\mathrm{La}_{0.3} \mathrm{Sr}_{0.7} \mathrm{Fe}(\mathrm{Al}, \mathrm{Cr}) \mathrm{O}_{3-\delta}$ ceramics, J. Eur. Ceram. Soc. 2005;25: 2603-2607.

18. Porras-vázquez JM, Santos-gómez L, Slater PR, Marrero-lópez D, Losilla ER. Crystallochemistry and electrical properties of Al-doped $\mathrm{Sr}_{2} \mathrm{SiO}_{4}$ electrolytes. Ceram Int 2016;42:16317-24.

19. Cioatera N, Rosculete C, Voinea E. The in fl uence of Al dopant on the structure, densification behavior and electrical conductivity of heavily doped $\mathrm{Sm}_{2} \mathrm{Ti}_{2} \mathrm{O}_{7}$ 2018;764:476-81.

20. Lach R, Kamecki B. Structural and electrical properties of Cr-doped $\mathrm{SrTiO}_{3}$ porous materials 2018:2-8.

21. Niu Y, Lv W, Chen D, Han J. A model study on correlation between microstructure-gas diffusion and Cr deposition in porous LSM / YSZ cathodes of solid oxide fuel cells. Int J Hydrogen Energy 2019;44:18319-29

22. Nenning A, Opitz A K, Rameshan C, Rameshan R, Blume R, Hävecker M, KnopGericke A, Rupprechter G, Klötzer B, Fleig J. Ambient Pressure XPS Study of Mixed Conducting Perovskite-Type SOFC Cathode and Anode Materials under Well-Defined Electrochemical Polarization, J. Phys. Chem. C. 2016;120: 1461-1471.

23. Sunding M F, Kepaptsoglou D M, Diplas S, Norby T, Gunnæs AE. XPS characterisation of the interface between anode and electrolyte in a proton conducting solid oxide fuel cell, Surf. Interface Anal. 2010;42:568-571.

24. Azad A K, Sanchez-Benitez J, Irvine J T S. Spin-glass transition $\mathrm{La}_{0.75} \mathrm{Sr}_{0.2} 5 \mathrm{Mn}_{0.5} \mathrm{Cr}_{0.5-\mathrm{x}} \mathrm{AlxO}_{3-\delta}$ Perovskites. Mater. Res. Bull. 2013;48: 2482-2490.

25. Werner P E, Eriksson L, Westdahl M. TREOR, a semi-exhaustive trial-and-error powder indexing program for all symmetries, J. Appl. Crystallogr. 1985;18: 367-370.

26. Lufaso M W, Woodward P M. Prediction of the crystal structures of perovskites using the software program SPuDS research papers. 2001;725-738.

27. Rodriguez-Carvajal J. Recent advances in magnetic structure determination by neutron powder diffraction + FullProf, Phys. B Condens. Matter. 1993;192:-55.

This article is protected by copyright. All rights reserved. 
28. Kim K, Jeong J, Azad A K, Jin S B, Kim J H. X-ray photoelectron spectroscopic study of direct reforming catalysts $\mathrm{Ln}_{0.5} \mathrm{Sr}_{0.5} \mathrm{Ti}_{0.5} \mathrm{Mn} 0.5 \mathrm{O}_{3 \pm \mathrm{d}}(\mathrm{Ln}=\mathrm{La}, \mathrm{Nd}$, and $\mathrm{Sm}$ ) for high temperature-operating solid oxide fuel cell, Appl. Surf. Sci. 2016;365:38-46.

29. Talik E, Kruczek M, Sakowska H, Szyrski W. XPS studies of chemically etched surfaces of $(\mathrm{La}, \mathrm{Sr})(\mathrm{Al}, \mathrm{Ta}) \mathrm{O}_{3}$ single crystals, J. Alloys Compd. 2003;361:282-288.

30. Lam D J, Veal B W, Ellis DE. Electronic structure of lanthanum perovskites with 3d transition elements, Phys. Rev. B. 1980;22:5730-5739.

31. Rath M K, Ahn B G, Choi BH, Ji M J, Lee KT. Effects of manganese substitution at the B-site of lanthanum-rich strontium titanate anodes on fuel cell performance and catalytic activity, Ceram. Int. 2013;39: 6343-6353.

32. Siebert A, Hammouche E, Kleitz M. Impedance spectroscopy analysis of $\mathrm{La}_{1-}$ ${ }_{\mathrm{x}} \mathrm{Sr}_{\mathrm{x}} \mathrm{MnO}_{3}$-yttria-stabilized zirconia electrode kinetics, Electrochim. Acta. 1995;40: $1741-1753$.

33. Fu Q X, Tietz F, Stöver D. $\mathrm{La}_{0.4} \mathrm{Sr}_{0.6} \mathrm{Ti}_{1-\mathrm{x}} \mathrm{Mn}_{\mathrm{x}} \mathrm{O}_{3-\delta}$ Perovskites as Anode Materials for Solid Oxide Fuel Cells, J. Electrochem. Soc. 2006;153: D74-D83.

34. Tao S, Irvine J T S. Synthesis and Characterization of $\left(\mathrm{La}_{0.75} \mathrm{Sr}_{0.25}\right) \mathrm{Cr}_{0.5} \mathrm{Mn}_{0.5} \mathrm{O}_{3-\delta}$, a Redox-Stable, Efficient Perovskite Anode for SOFCs, J. Electrochem. Soc. 2004;151:A252-A259.

35. Tsurkan V, Demeter M, Schneider B, Hartmann D, Neumann M. Exchange splitting of the $\mathrm{Cr}, \mathrm{Fe}$ and Mn 3s XPS spectra in some ternary magnetic semiconductor sulphides, Solid State Commun. 2000;114: 149-154.

36. Daulton T L, Little B J, Determination of chromium valence over the range $\mathrm{Cr}(\mathrm{O})$ Cr(VI) by electron energy loss spectroscopy, Ultramicroscopy. 2006;561-573.

37. Liu J, Fan K, Tian W, Liu C, Rong L. Hydroprocessing of Jatropha oil over NiMoCe/ $\mathrm{Al}_{2} \mathrm{O}_{3}$ catalyst, Int. J. Hydrogen Energy. 2012;37: 17731-17737.

38. Di Castro V, Polzonetti G. XPS study of MnO oxidation, J. Electron Spectros. Relat. Phenomena. 1989;48: 117-123.

39. Aronniemi M, Sainio J, Lahtinen J. Chemical state quantification of iron and chromium oxides using XPS: The effect of the background subtraction method, Surf. Sci. 2005;578: 108-123.

40. Koo J, Kim S, Jeon S, Jeon H, Kim Y. Characteristics of $\mathrm{Al}_{2} \mathrm{O}_{3}$ Thin Films Deposited Using Dimethylaluminum Isopropoxide and Trimethylaluminum Precursors by the Plasma-Enhanced Atomic-Layer Deposition Method, J. Korean Phys. Soc. 2006;48: 131-136.

This article is protected by copyright. All rights reserved. 
41. Smith S J, Huang B, Bartholomew C H, Campbell B J, Boerio-Goates J, Woodfield B F. La-Dopant Location in La-Doped $\gamma-\mathrm{Al}_{2} \mathrm{O}_{3}$ Nanoparticles Synthesized Using a Novel One-Pot Process, J. Phys. Chem. C. 2015;119:25053-25062.

42. Boukha Z, L Fitian, pez-Haro M L, Mora M, Ruiz J R, Jimnez-Sanchidrin C, et al. Influence of the calcination temperature on the nano-structural properties, surface basicity, and catalytic behavior of alumina-supported lanthana samples, J. Catal. 2010;272: 121-130.

43. Van Dillen A J, Terörde R J A M, Lensveld D J, Geus J W, De Jong K P. Synthesis of supported catalysts by impregnation and drying using aqueous chelated metal complexes, J. Catal. 2003;216: 257-264.

44. Beguin B, Garbowski E, Primet M. Stabilization of alumina by addition of lanthanum, Appl. Catal. 1991;75:119-132.

45. Schaper H, Doesburg E B M, Van Reijen LL. The influence of lanthanum oxide on the thermal stability of gamma alumina catalyst supports, Appl. Catal. 1983;7:211-220.

46. Wang S, Borisevich A Y, Rashkeev S N, Glazoff M V, Sohlberg K, Pennycook S J, et al. Dopants adsorbed as single atoms prevent degradation of catalysts, Nat. Mater. 2004;3: 143-146..

47. Ponce S, Peña M A, Fierro J L G. Surface properties and catalytic performance in methane combustion of SR-substituted lanthanum manganites, Appl. Catal. B Environ. 2000;24: 193-205.

Figure and Table Caption List:

Figure 1: Rietveld refinement profile of XRD data of $\mathrm{La}_{0.75} \mathrm{Sr}_{0.25} \mathrm{Mn}_{0.5} \mathrm{Cr}_{0.3} \mathrm{Al}_{0.2} \mathrm{O}_{3-\delta}$ in the rhombohedral symmetry.

Figure 2: Total conductivity of $\mathrm{La}_{0.75} \mathrm{Sr}_{0.25} \mathrm{Mn}_{0.5} \mathrm{Cr}_{0.3} \mathrm{Al}_{0.2} \mathrm{O}_{3-\delta}(\mathrm{x}=\mathbf{0 . 1}, \mathbf{0 . 2}, 0.3)$ in (a) wet $5 \% \mathrm{H} 2$, (b) dry $5 \% \mathrm{H} 2$ and (c) air at different temperatures.

Figure 3: Change of isothermal conductivity with oxygen partial pressure for $x=0.1$ (a) and $x=0.2$ (b) at $900 \mathrm{oC}$, dotted line corresponds to slope of 1/12.

Figure 4: Wide spectra of $\mathrm{La}_{0.75} \mathrm{Sr}_{0.25} \mathrm{Mn}_{0.5} \mathrm{Cr}_{0.3} \mathrm{Al}_{0.2} \mathrm{O}_{3-\delta}(x=0.1,0.2,0.3)$ oxide in air and $\mathrm{H} 2$.

Figure 5: XPS measurement plots for $\mathrm{Mn}$ and $\mathrm{Cr}$ on as-prepared samples for different percentage of Al doping. For $\mathrm{Mn}$ (a to c) and for $\mathrm{Cr}$ (d to f) for $\mathrm{x}=0.1,0.2$, and 0.3 , respectively. 
Figure 6: XPS measurement plots for $\mathrm{Mn}$ and $\mathrm{Cr}$ on pre-reduced samples for different percentage of Al doping. For $\mathrm{Mn}$ (a to c) and for $\mathrm{Cr}(\mathrm{d}$ to $\mathrm{f}$ ) for $\mathrm{x}=0.1,0.2$, and 0.3 , respectively.

Figure 7: XPS plots for Al (a ,b,c for as-prepared samples and d,e is for pre-reduced samples).

Figure 8: XPS plots for $O$ 1s for pre-reduced samples of $a, b$ and $c$ for $x=0.1,0.2,0.3$, respectively.

Table 1: Main crystallographic structure information for $\mathrm{La}_{0.75} \mathrm{Sr}_{0.25} \mathrm{Mn}_{0.5} \mathrm{Cr}_{0.3} \mathrm{Al}_{0.2} \mathrm{O}_{3-\delta}$ $(x=0.1,0.2,0.3)$ in the rhombohedral (space group $\mathrm{R}-3 \mathrm{C}$ ) from XRD data refinement.

Table 2. Calculated conductivity for AC mode of $\mathrm{La}_{0.75} \mathrm{Sr}_{0.25} \mathrm{Mn}_{0.5} \mathrm{Cr}_{0.5-\mathrm{x}} \mathrm{Al}_{\mathrm{x}} \mathrm{O}_{3-\delta}(\mathrm{x}=0.1$, 0.2, 0.3).

Table 3. Binding energies (eV) of core electrons $\mathrm{La}_{0.75} \mathrm{Sr}_{0.25} \mathrm{Mn}_{0.5} \mathrm{Cr}_{1-\mathrm{x}} \mathrm{Al}_{\mathrm{x}} \mathrm{O}_{3-\delta}(\mathrm{x}=0.1$, $0.2,0.3)$ on as-prepared and pre-reduced samples. 
Table 1. Main crystallographic structure information for $\mathrm{La}_{0.75} \mathrm{Sr}_{0.25} \mathrm{Mn}_{0.5} \mathrm{Cr}_{0.5-\mathrm{x}} \mathrm{Al}_{\mathrm{x}} \mathrm{O}_{3-\delta}$ ( $\mathrm{x}=$ $0.1,0.2,0.3$ ) in the rhombohedral (space group R-3C) from XRD data refinement.

\begin{tabular}{|l|l|l|l|}
\hline \multicolumn{1}{|l|}{} & $\mathrm{x}=0.1$ & $\mathrm{x}=0.2$ & $\mathrm{x}=0.3$ \\
\hline$a=b(\AA)$ & $5.4897(2)$ & $5.4791(4)$ & $5.4782(6)$ \\
\hline$V(\AA)$ & $13.3086(6)$ & $13.2974(1)$ & $13.3031(5)$ \\
\hline $\mathrm{La} / \mathrm{Sr}$ in $6 a(0,0,0.25)$ & $345.70(4)$ & $345.75(7)$ \\
\hline $\mathrm{B}\left(\AA^{2}\right)$ & $347.35(3)$ & $0.74(6)$ & $0.75(3)$ \\
\hline $\mathrm{Mn} / \mathrm{Cr} / \mathrm{Al}$ in $6 b(0,0,0)$ & \multicolumn{2}{l|}{} \\
\hline $\mathrm{B}\left(\AA^{2}\right)$ & $0.85(3)$ & $0.90(4)$ & $0.85(6)$ \\
\hline $\mathrm{O}$ in $18 e$ in $(\mathrm{x}, 0,0.25)$ & \multicolumn{2}{l|}{} \\
\hline$X$ & $0.453(1)$ & $0.455(2)$ & $0.458(2)$ \\
\hline $\mathrm{R}_{\mathrm{p}}(\%)$ & 2.24 & 3.07 & 3.17 \\
\hline $\mathrm{R}_{\mathrm{wp}}(\%)$ & 2.90 & 6.03 & 4.65 \\
\hline $\mathrm{R}_{\exp }(\%)$ & 4.45 & 6.82 & 5.09 \\
\hline $\mathrm{R}_{\mathrm{B}}(\%)$ & 3.55 & 6.27 \\
\hline
\end{tabular}


Table 2. Calculated conductivity for $\mathrm{AC}$ mode of $\mathrm{La}_{0.75} \mathrm{Sr}_{0.25} \mathrm{Mn}_{0.5} \mathrm{Cr}_{0.5-\mathrm{x}} \mathrm{Al}_{\mathrm{x}} \mathrm{O}_{3-\delta}(\mathrm{x}=0.1,0.2$, $0.3)$

\begin{tabular}{|l|l|l|l|l|}
\cline { 3 - 5 } \multicolumn{2}{c|}{} & \multicolumn{3}{|l|}{ AC conductivity (From Fig. 2) } \\
\cline { 3 - 5 } \multicolumn{2}{c|}{} & Wet $5 \% \mathrm{H}_{2}$ & Dry $5 \% \mathrm{H}_{2}$ & Air \\
\hline \multirow{3}{*}{$\mathrm{x}=0.1$} & Conductivity & 0.46 & 0.39 & 0.25 \\
\cline { 2 - 5 } & Activation energy & 0.087 & 0.26 & 0.34 \\
\hline \multirow{2}{*}{$\mathrm{x}=0.2$} & Conductivity & 0.32 & 0.14 & 0.16 \\
\cline { 2 - 5 } & Activation energy & 0.069 & 0.22 & 0.33 \\
\hline & Conductivity & 0.30 & 0.24 & 0.17 \\
\cline { 2 - 5 } & Activation energy & 0.084 & 0.31 & 0.41 \\
\hline
\end{tabular}


Table 3. Binding energies (eV) of core electrons $\mathrm{La}_{0.75} \mathrm{Sr}_{0.25} \mathrm{Mn}_{0.5} \mathrm{Cr}_{1-\mathrm{x}} \mathrm{Al}_{\mathrm{x}} \mathrm{O}_{3-\delta}(\mathrm{x}=0.1,0.2$, $0.3)$ on as-prepared and pre-reduced samples.

\begin{tabular}{|c|c|c|c|c|c|c|}
\hline Sample & C $1 \mathrm{~s}$ & $\begin{array}{l}\text { Sr 3p } p_{1 / 2} \\
\text { Sr 3p } 3 / 2\end{array}$ & $\begin{array}{l}\text { Mn } 2 p_{3 / 2} \\
\operatorname{Mn} 2 p_{1 / 2}\end{array}$ & $\begin{array}{l}\text { Cr } 2 p_{3 / 2} \\
\text { Cr } 2 p_{1 / 2}\end{array}$ & $\mathrm{Al} 2 \mathrm{p}$ & $\mathrm{O} 1 \mathrm{~s}$ \\
\hline \multicolumn{7}{|c|}{ As-prepared samples } \\
\hline$x=0.1$ & 284.58 & 278.57 & $\begin{array}{l}641.90 \\
653.60\end{array}$ & $\begin{array}{l}576.07 \\
-\end{array}$ & - & - \\
\hline $\mathrm{x}=0.2$ & 284.61 & $\begin{array}{l}278.39 \\
268.20\end{array}$ & $\begin{array}{l}641.39 \\
652.91\end{array}$ & $\begin{array}{l}575.51 \\
585.20\end{array}$ & 72.935 & - \\
\hline$x=0.3$ & 286.54 & $\begin{array}{l}278.88 \\
270.78\end{array}$ & $\begin{array}{l}644.22 \\
655.57\end{array}$ & $\begin{array}{l}578.43 \\
587.86\end{array}$ & 75.01 & - \\
\hline \multicolumn{7}{|c|}{ Pre-reduced samples } \\
\hline$x=0.1$ & 285.01 & $\begin{array}{l}278.75 \\
268.76\end{array}$ & $\begin{array}{l}643.89 \\
655.24\end{array}$ & $\begin{array}{l}577.55 \\
587.66\end{array}$ & $\begin{array}{l}71.90 \\
76.92\end{array}$ & 530.62 \\
\hline$x=0.2$ & 284.71 & $\begin{array}{l}275.68 \\
269.09\end{array}$ & $\begin{array}{l}645.03 \\
656.19\end{array}$ & $\begin{array}{l}579.08 \\
589.20\end{array}$ & 75.22 & 532.52 \\
\hline$x=0.3$ & 284.32 & $\begin{array}{l}279.60 \\
274.36\end{array}$ & $\begin{array}{l}643.43 \\
655.00\end{array}$ & $\begin{array}{l}578.04 \\
588.25\end{array}$ & 74.64 & 531.01 \\
\hline
\end{tabular}



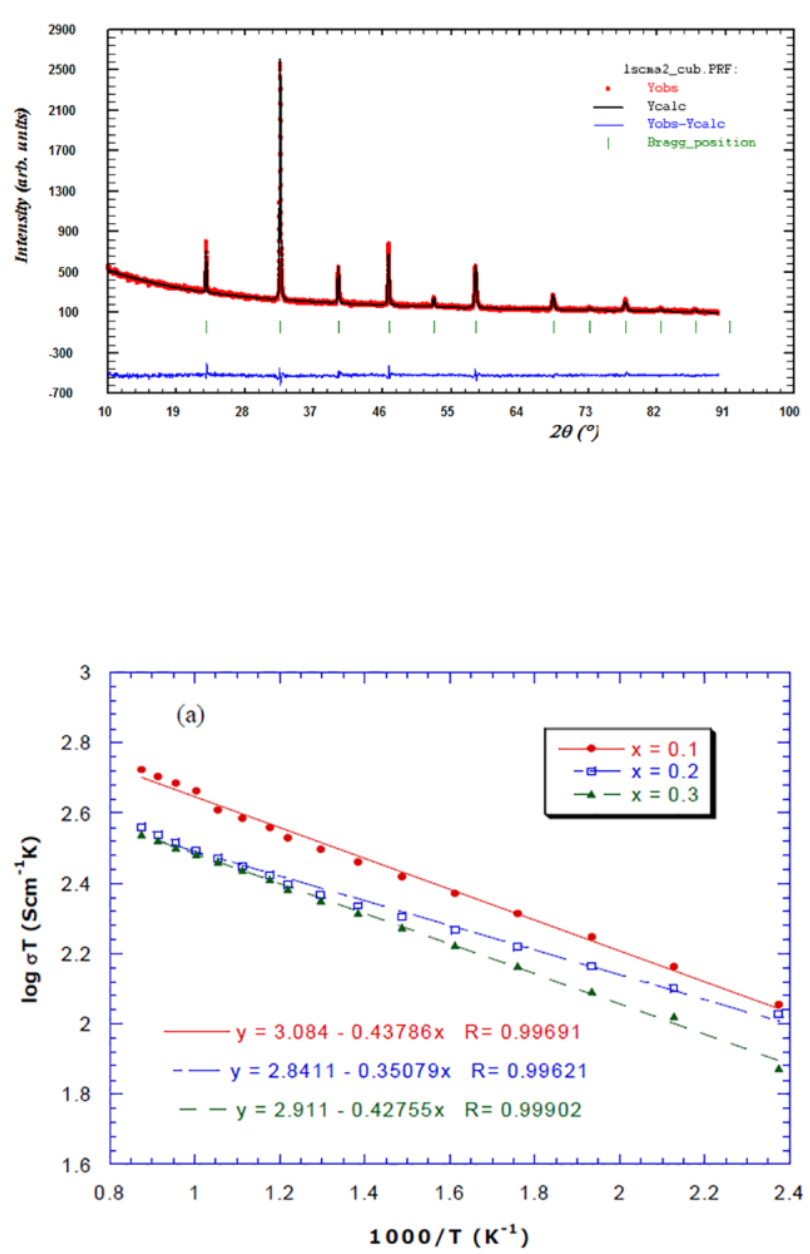

This article is protected by copyright. All rights reserved. 

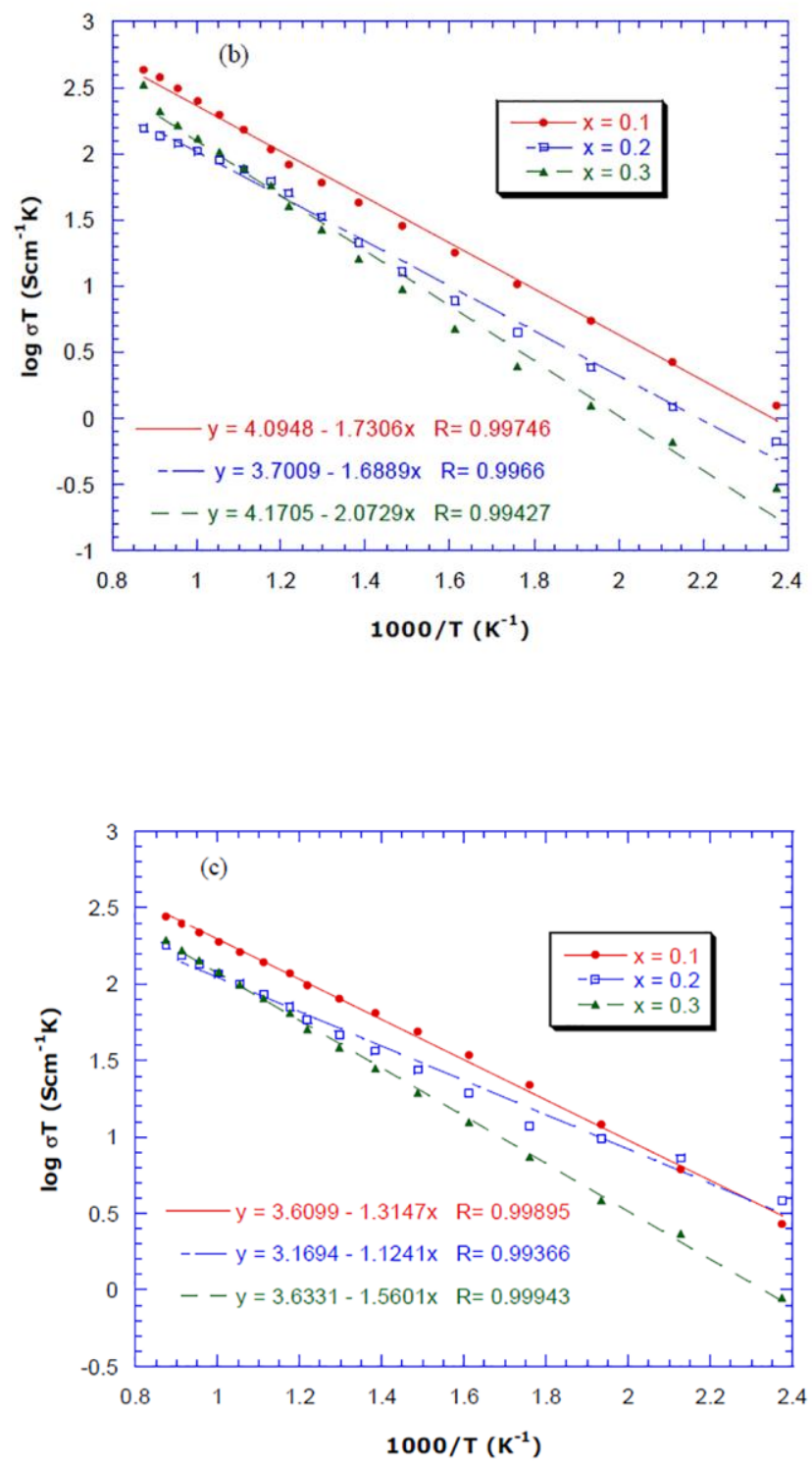

This article is protected by copyright. All rights reserved. 

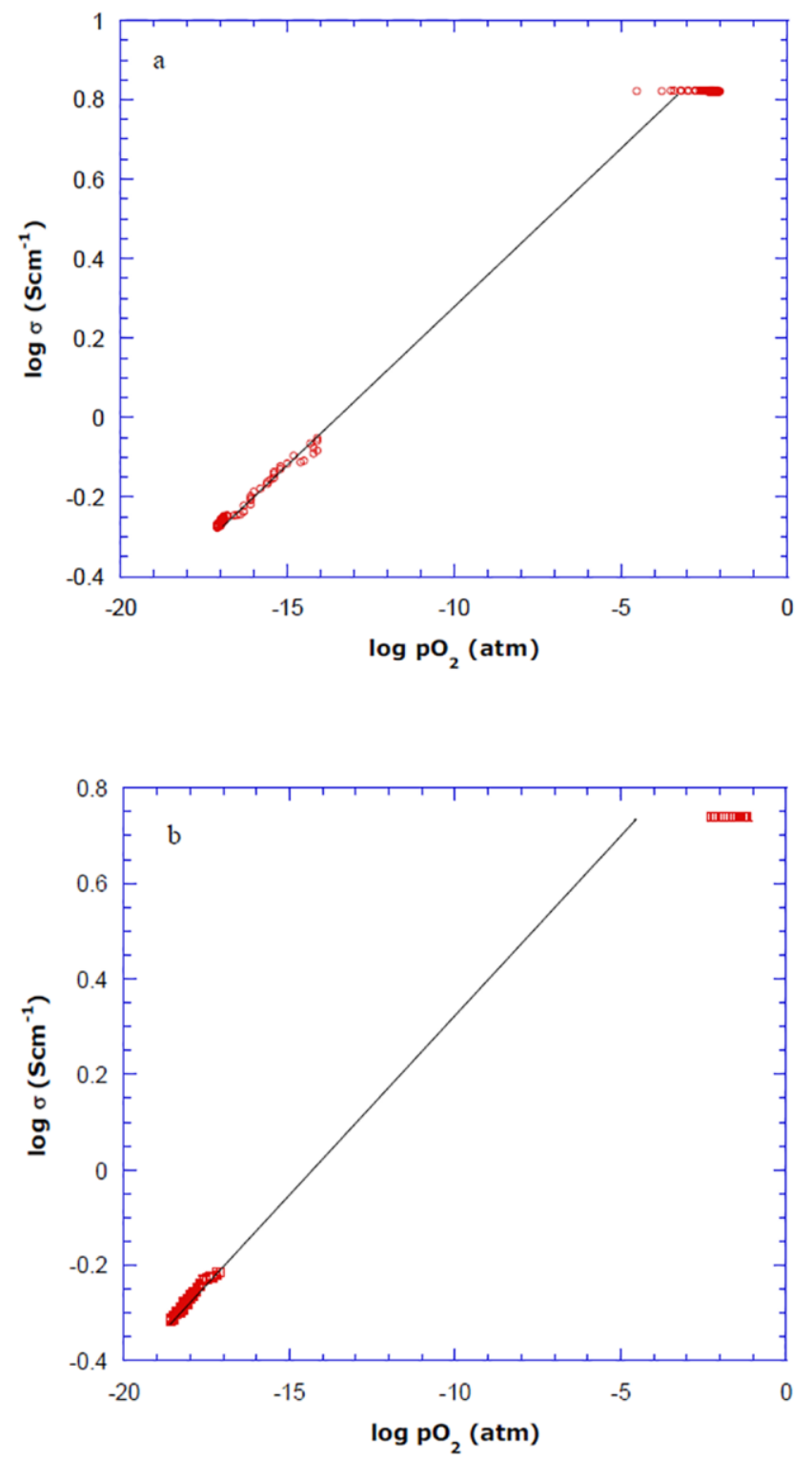

This article is protected by copyright. All rights reserved. 

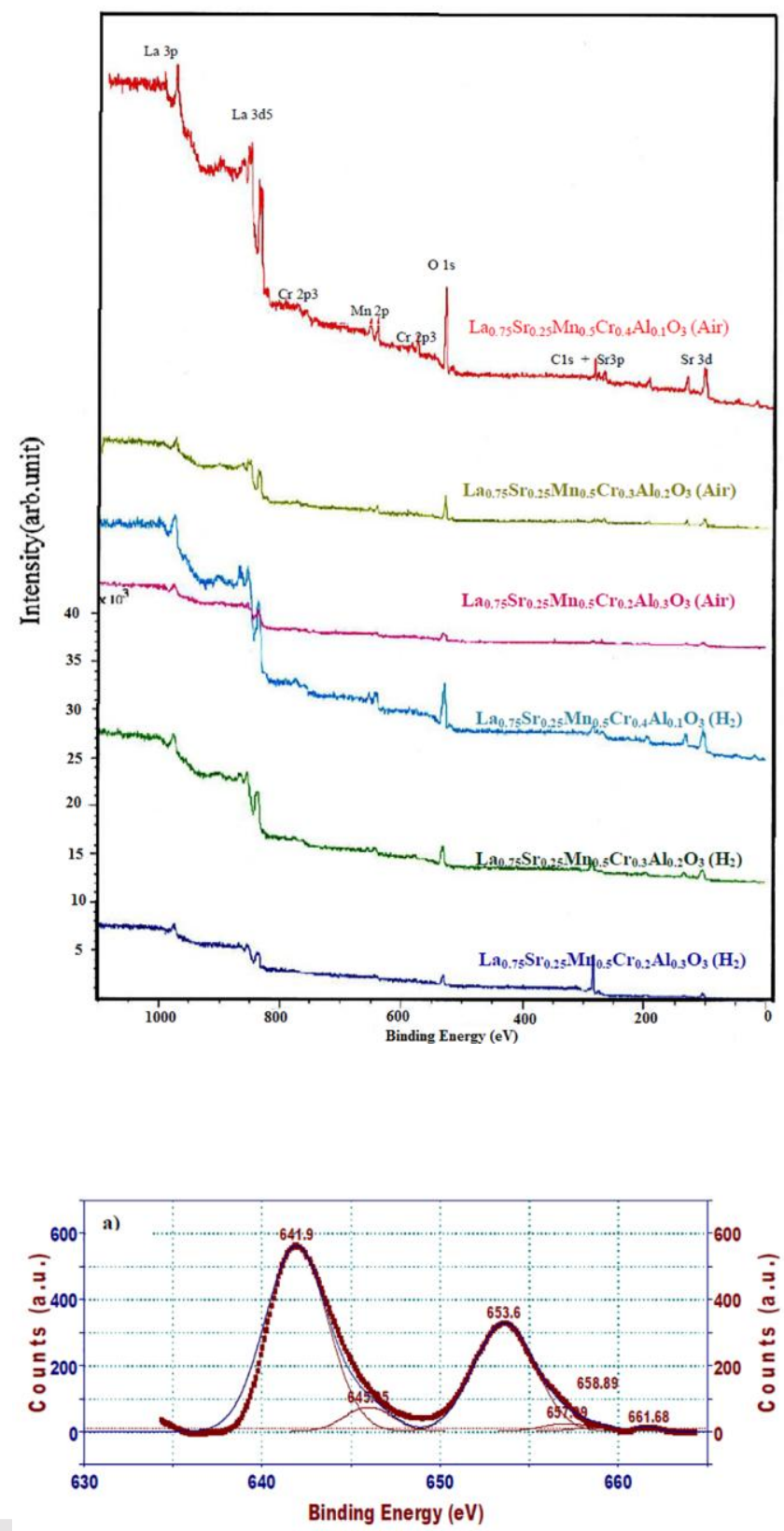

This article is protected by copyright. All rights reserved. 

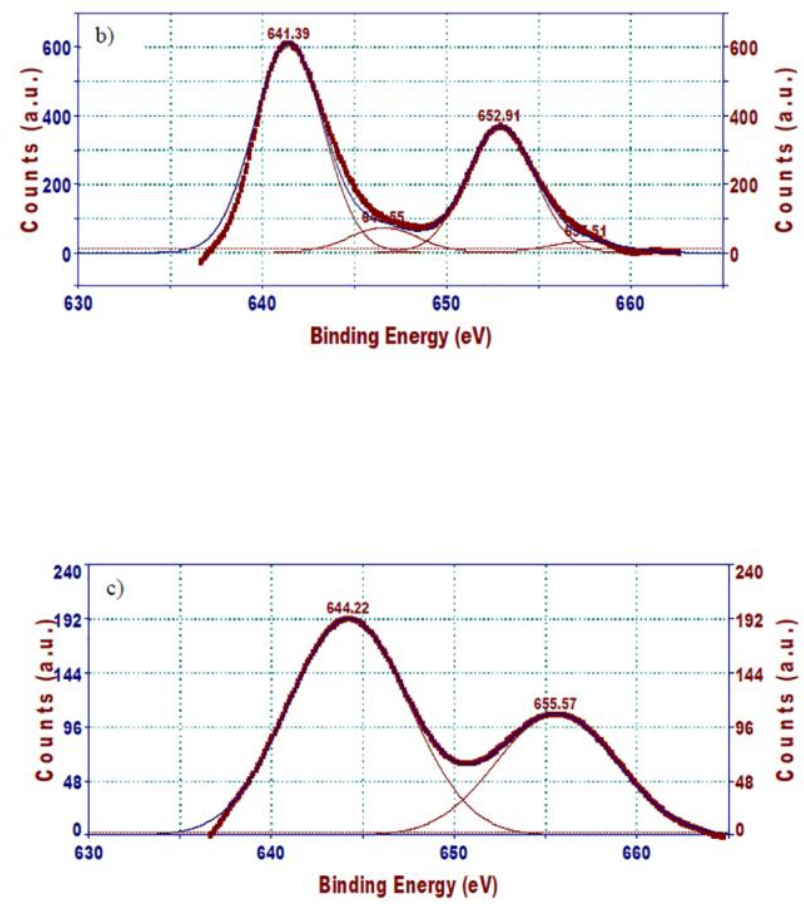

This article is protected by copyright. All rights reserved. 

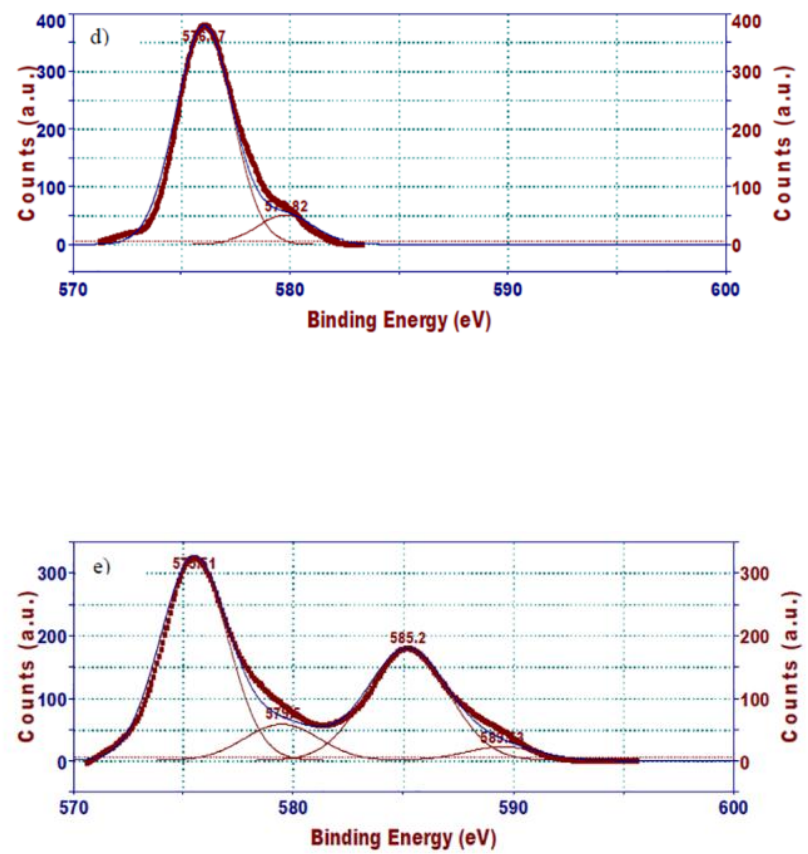

This article is protected by copyright. All rights reserved. 

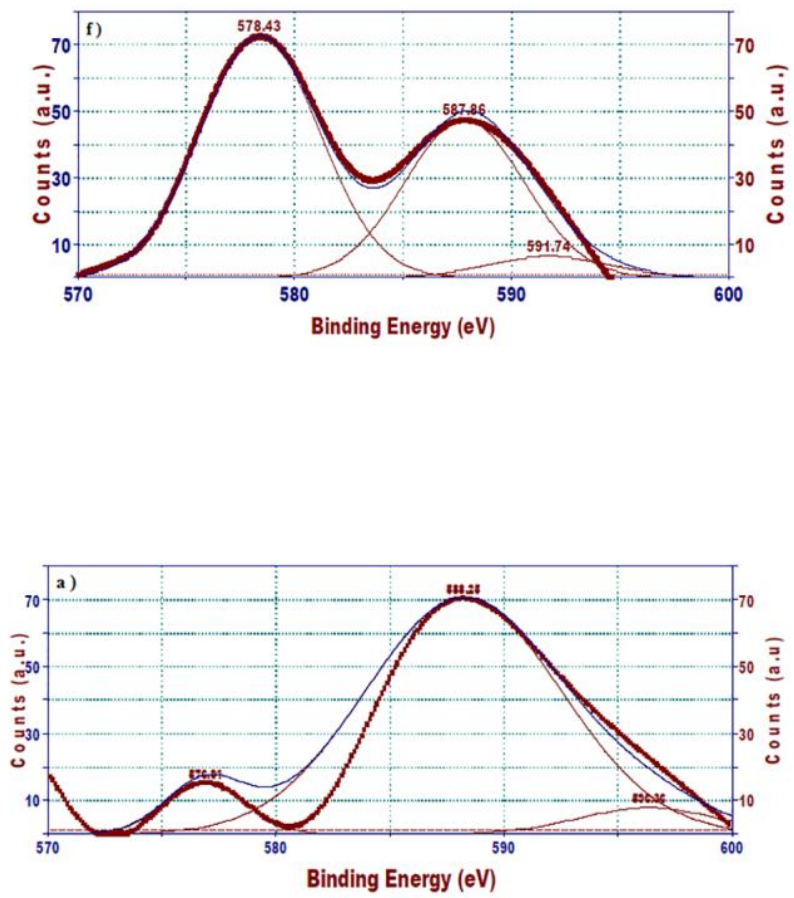

This article is protected by copyright. All rights reserved. 

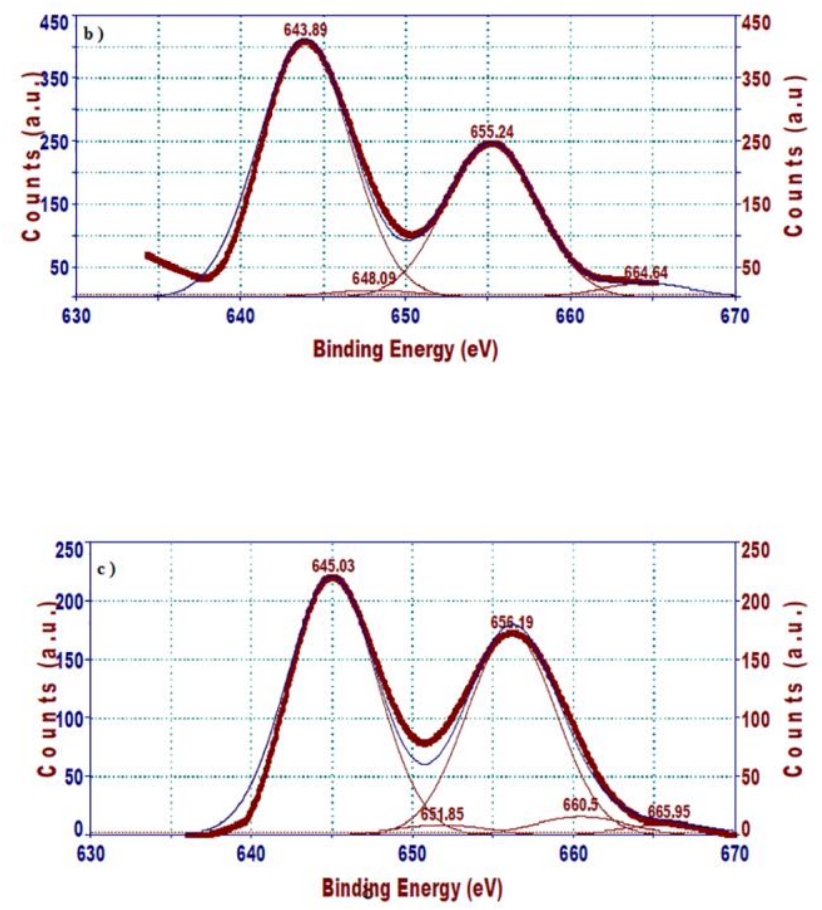

This article is protected by copyright. All rights reserved. 

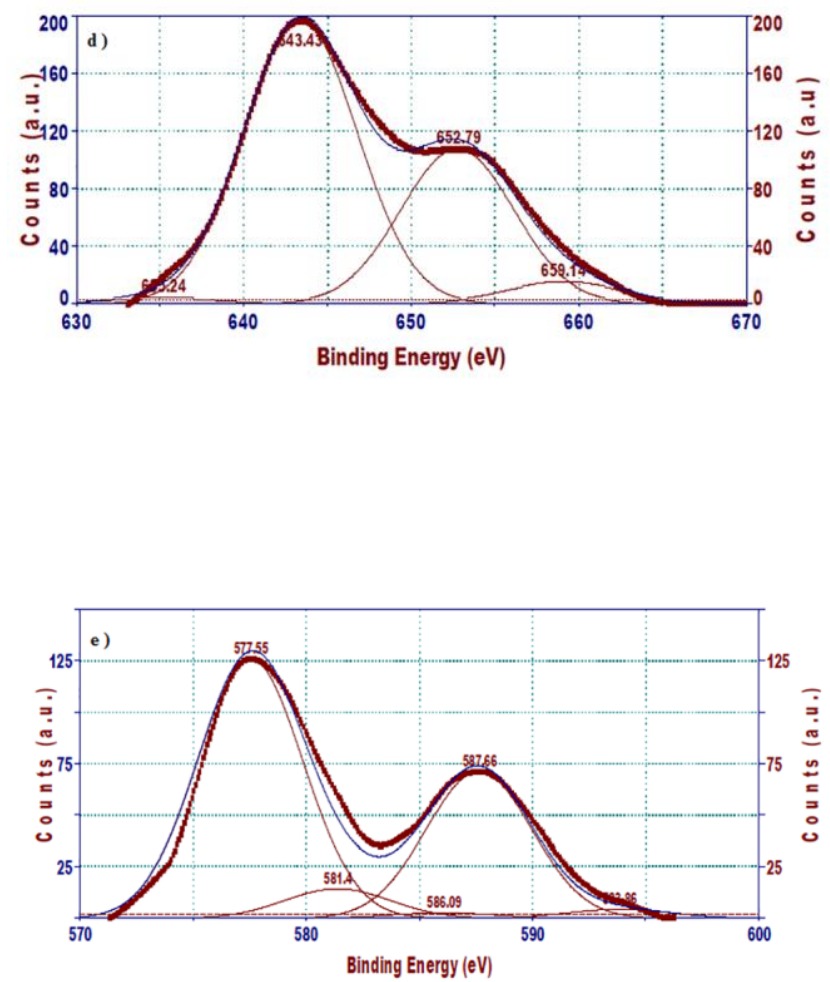

This article is protected by copyright. All rights reserved. 

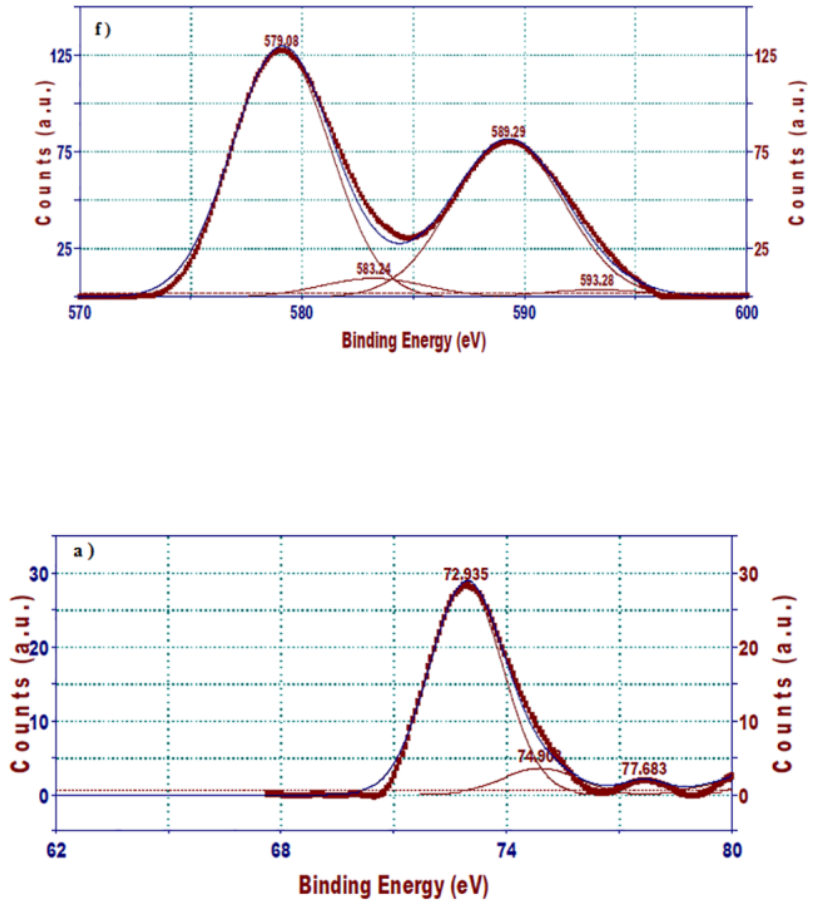

This article is protected by copyright. All rights reserved. 

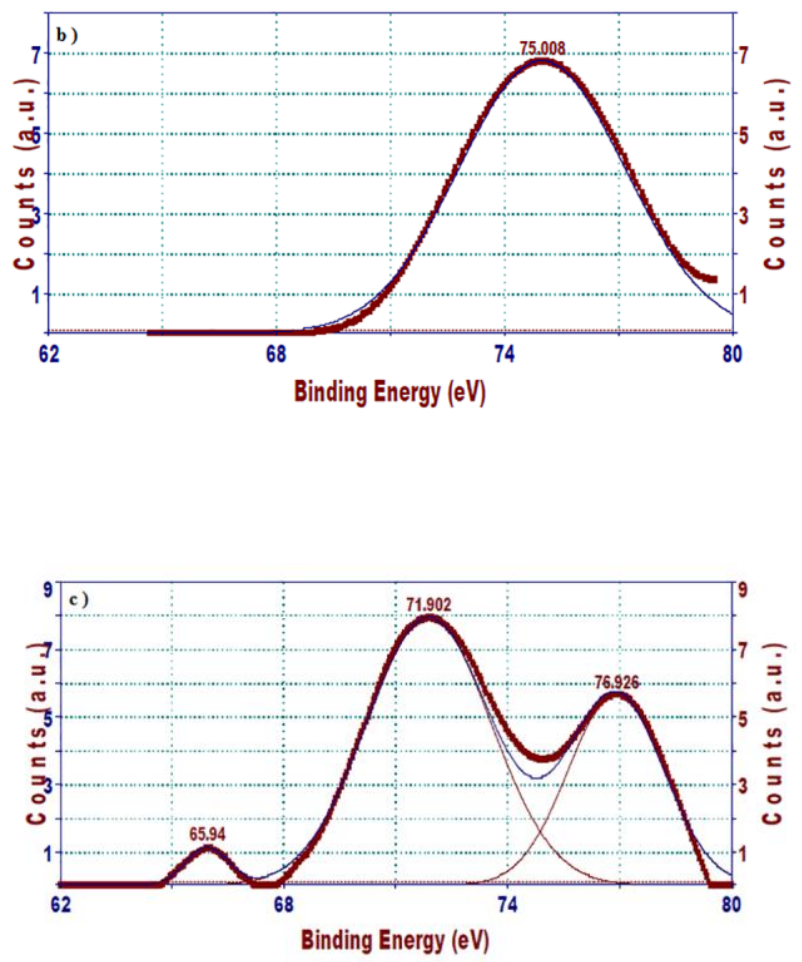

This article is protected by copyright. All rights reserved. 

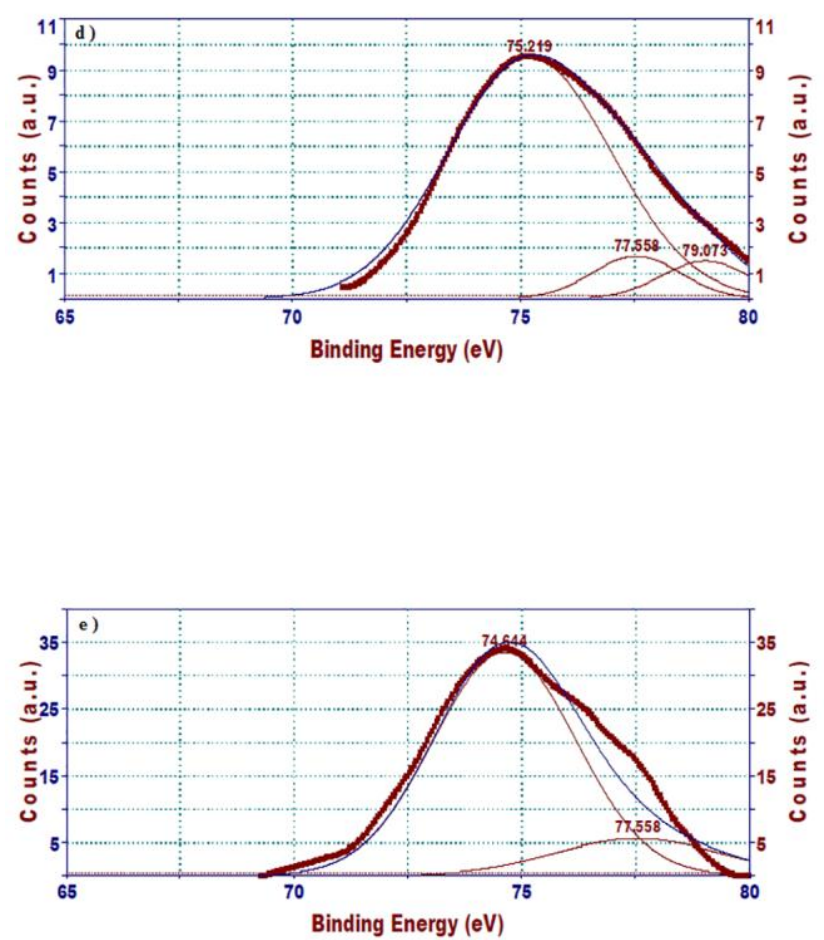

This article is protected by copyright. All rights reserved. 

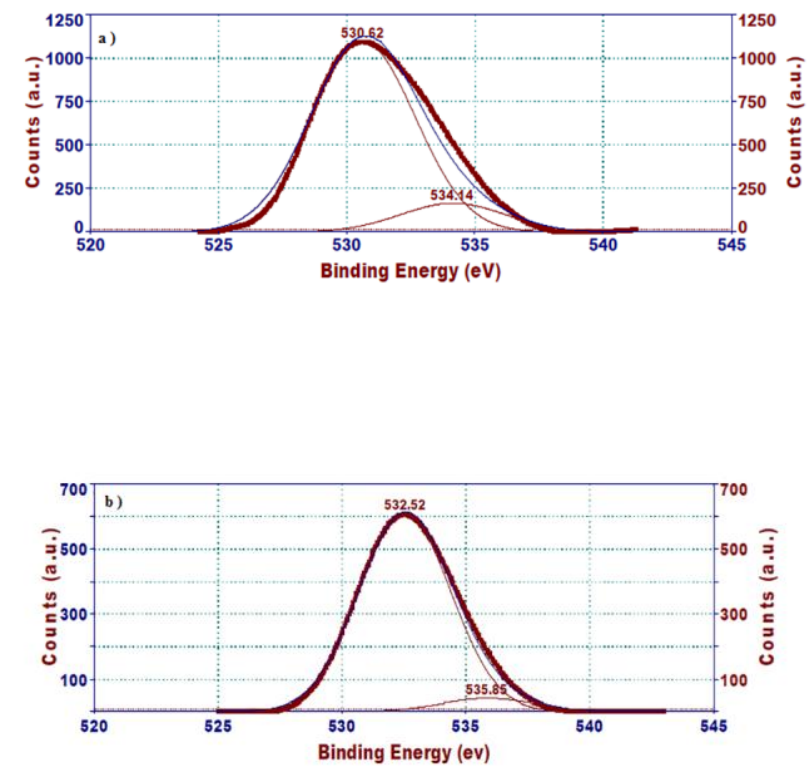

This article is protected by copyright. All rights reserved. 


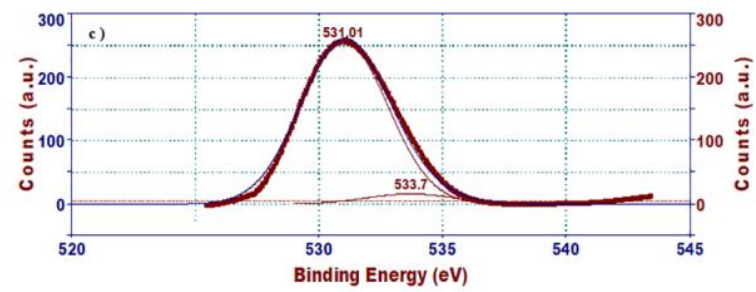

This article is protected by copyright. All rights reserved. 